STANISEAW ROSIK

Instytut Historyczny

Uniwersytetu Wrocławskiego

\title{
CHRZEST MIESZKA I I POLAKÓW, ALE CZY POLSKI? POSTRZEGANIE KONWERSJI WŁADCY I SPOŁECZEŃSTWA W ŚWIETLE NAJDAWNIEJSZYCH PRZEKAZÓW (THIETMAR Z MERSEBURGA, GALL ANONIM)
}

Upamiętniając po blisko półwieczu chrzest Mieszka I i jego poddanych, Thietmar z Merseburga (zm. 1018), stworzył wzniosły obraz literacki, pomnikowy, a tym samym dość schematyczny: „Trudziła się bowiem [Dobrawa] nad nawróceniem swego męża i została wysłuchana przez łaskawość swego Stwórcy, dzięki którego nieskończonej dobroci jego zagorzały prześladowca opamiętał się, gdy za sprawą licznych namów swojej umiłowanej żony wyrzucił z siebie jad wrodzonej niewierności i w świętym chrzcie zmył pierworodną zmazę. I wnet idą za swą głową i umiłowanym panem członki ludu dotąd ułomne i przyjąwszy weselną szatę zostają zaliczone między pozostałe przybrane potomstwo Chrystusa. Pierwszy ich biskup, Jordan, bardzo się z nimi natrudził, zanim zdołał ich czynem i słowem nakłonić do uprawy niebiańskiej winnicy"1.

Już w samym dowartościowaniu wpływu małżonki na nawrócenie władcy trudno nie dopatrywać się realizacji toposu², jak też w uznaniu

1 „Laboravit enim pro conversione coniugis sui ac exaudita est a benignitate Conditoris sui, cuius infinita bonitate persecutor suimet studiosus resipuit, dum crebro dilectae uxoris ortatu innatae infidelitatis toxicum evomuit et in sacro baptismate nevam originalem detersit. Et protinus caput suum et seniorem dilectum membra populi hactenus debilia subsequuntur et nupciali veste recepta inter caeteros Christi adoptivos numerantur. Iordan, primus eorum antistes, multum cum eis sudavit, dum eos ad supernae cultum vineae sedulus verbo et opere invitavit", por. Kronika Thietmara, tekst łac.i pol., wyd. i tłum. M.Z. Jedlicki, Poznań 1953 [dalej: Thietmar], IV, 56.

${ }^{2}$ Topos „mulier suadens”, szerzej zob. zob. np. J. Banaszkiewicz, Dąrówka „christianissima" i Mieszko poganin (Thietmar, IV, 55-56; Gall, I, 5-6), w: Nihil superfluum esse. Prace 
Mieszka za „prześladowcę” samego Stwórcy ${ }^{3}$. Podobnie stereotypowo rysuje się przedstawienie lakonicznej wykładni teologii udzielonego mu chrztu, kontynuowanej także w dalszych słowach odnoszących się do jego poddanych, gdy mowa o przybraniu przez nich weselnej szaty i zaliczeniu ich do przybranego potomstwa Chrystusa. Za sprawą organicystycznej metafory - caput et membra populi - lud Mieszka przedstawia się w tym ujęciu jako jedna, złożona z chrześcijan, społeczność skupiona nie tylko wokół monarchy, ale i współpracującego z nim biskupa.

Można mówić tu więc o pełni sukcesu konwersji w wymiarze życia zbiorowego, który jednak został w upowszechnionym za sprawą kilkukrotnych wydań polskim przekładzie Kroniki Thietmara istotnie umniejszony. Otóż w tłumaczeniu sformułowania membra populi pojawiło się nieobecne w łacinie „spośród”, by w ten sposób mówić o nawróconych „członkach spośród ludu” raz jedynie zaczątku konwersji ogółu poddanych Mieszka I, a nie całości ludu (populus). Tak podretuszowany przekaz dobrze koresponduje $\mathrm{z}$ utrwalonym $\mathrm{w}$ historiografii XX w. metaforycznym rozumieniem „chrztu Polski” jako wielopokoleniowego procesu likwidacji pogaństwa oraz zaprowadzania chrześcijaństwa w skali całego kraju ${ }^{5}$.

W optymistycznej wersji kończy się ów etap społecznej transformacji wraz z powstaniem sieci parafialnej (XII/XIII w.). Pesymiści jednak, podkreślając dłuższe trwanie tzw. przeżytków pogaństwa, rozciągają ten okres aż do progu czasów nowożytnych, ale jeśli tak, to warto zastanowić się, czy w ogóle można go zamknąć. Wszak do dziś w kulturze wciąż można dopatrzyć się jakichś przedchrześcijańskich reliktów, a poza tym trudno nie zauważać rozmaitych alternatyw dla chrystianizmu powstających na jego bazie (magia itd.) już od wieków średnich czy ruchów promujących dechrystianizację zwłaszcza w ostatnich stuleciach; osobnym zagadnieniem będzie w tym wypadku kohabitacja z wyznawcami innych religii już od średniowiecza.

Dlatego warto podkreślić, że u podstaw metafory „chrztu Polski” legło przekonanie, że istniała Polska pogańska, która przeszła religijną przemianę, nawrócenie na chrześcijaństwo, a ten z kolei obraz uwarunkowany został abstrakcyjnym pojmowaniem monarchii, względnie narodu i państwa, jako zantropomorfizowanego podmiotu działającego

z dziejów średniowiecza ofiarowane Profesor Jadwidze Krzyżaniakowej, red. J. Dobosz, J. Strzelczyk, Poznań 2000, s. 85-93.

${ }^{3}$ Już w Dziejach Apostolskich (9, 3-9) św. Paweł ukazany został jako prześladowca nie tylko chrześcijan, ale i samego Chrystusa.

${ }^{4}$ Thietmar, IV, 56, s. 222.

${ }^{5}$ Klasyczne ujęcie zob. J. Dowiat, Chrzest Polski, Warszawa 1960. 
na scenie dziejów. Siła oddziaływania tak pojętej idei Polski owładnęła już umysłem Galla Anonima, gdy kreślił jej wizję jako „ślepej w ciemnościach niewiary", a następnie oświeconej, zyskującej wzrok przez chrzest Mieszka ${ }^{6}$. Podobnie znaczenie tego aktu, jako przyłączenie kraju i jego mieszkańców do chrześcijańskiej wiary, wykładał Jan Długosz ${ }^{7}$. Nie przypadkiem więc wciąż obecne jest w szerokim obiegu społecznym uznawanie roku 966 za datę „chrztu Polski”, a wspomniana wyżej propozycja procesualnej, długofalowej interpretacji tej metafory to w istocie próba odmitologizowania zawartego w niej archetypowego obrazu, konstytuującego zbiorową pamięć o polskich początkach.

$\mathrm{Z}$ tego rodzaju mitem wygrywać niełatwo, a przy tym nasuwa się pytanie, czy z respektu dla pozytywistycznego „szkiełka i oka” akurat w tym wypadku warto taką walkę toczyć. W ten sposób bowiem pejoratywnie wartościuje się istotne zagadnienie z obszaru historii kultury, a konkretnie ogląd przełomowych wydarzeń sprzed tysiąca lat w pamięci kolejnych pokoleń. W omawianym tu przypadku znaczące jest zresztą nie tylko samo postrzeganie zamierzchłych czasów, ich mitologizacja, ale także możliwość wydobycia na tej podstawie istotnej wiedzy o rozumieniu procesów chrystianizacji na najdawniejszym ich etapie, jeszcze przez ich uczestników czy obserwatorów, co dodatkowo ma walor poznawczy w określaniu czynników decydujących o zaprowadzaniu nowej religii.

Otóż określone idee teologiczne dochodzące do głosu w uchwytnej źródłowo interpretacji wypieranej rodzimej religii i zaprowadzania chrystianizmu (np. oświecenie przez wiarę, wyzwolenie z więzów zła czy panowania szatana) stymulowały działalność samych misjonarzy czy duszpasterzy przez kolejne pokolenia parających się rugowaniem reliktów dawnych rytów i wierzeń, a także nauczaniem ludności i wdrażaniem jej w praktykowanie kultu kościelnego. Co więcej, samo tak czytelnie wyrażone antropomorfizmem chrztu uznanie danego kraju i ludu za chrześcijański, polegające na nadaniu - a na ogół także recepcji - określonej tożsamości grupowej, stanowi zjawisko w obiegu społeczno-kulturowym, które warto rozpatrywać również jako jeden z katalizatorów procesów chrystianizacyjnych.

${ }^{6}$ Galli Anonymi Cronicae et gesta ducum sive principum Polonorum, wyd. K. Maleczyński, Cracoviae 1952, MPH n.s., t. 2, I, 4.

${ }^{7}$ Joannis Dlugossii Annales seu Cronicae incliti Regni Poloniae, ks. 1-2, wyd. M. Plezia, Warszawa 1964, ks. 2, pod rokiem 965. W tej sprawie, z uwzględnieniem szerszego kontekstu średniowiecznej historiografii, ostatnio P. Węcowski, Początki Polski w pamięci historycznej późnego średniowiecza, Kraków 2014, s. 235-272. 
Przesłanki sprzyjające rozwinięciu metafory chrztu Polski można odnaleźć już w Gallowym przekazie ${ }^{8}$, jednakowoż w zawartej w nim wizji jej oświecenia upatrywać raczej należy jedynie dojście do głosu fundamentalnego poglądu wiążącego przełom chrystianizacyjny z konwersją władcy. Tenże nacisk na centralną rolę chrztu Mieszka w uczynieniu Polski chrześcijańską współbrzmi w zasadniczym przesłaniu z poglądem zawartym w przytoczonym wyżej, o stulecie wcześniejszym, obrazie Thietmara. Kluczowe znaczenie ma w tym wypadku model, który zakłada zaistnienie społeczności, zorganizowanej politycznie i skupionej jeszcze jako pogańskiej wokół władcy. Przyjęcie zaś chrztu przez jej głowę, a następnie resztę członków, dało asumpt do postrzegania całej tej zbiorowości (populus) jako chrześcijańskiej.

Merseburski kronikarz przypisuje wdrożenie jej w praktykowanie nowej religii Jordanowi, czym wskazuje, że uformowanie się tej chrześcijańskiej wspólnoty nie trwało zapewne dłużej niż kilka lat. Opinia ta brzmi wiarygodnie, zwłaszcza jeśli weźmie się pod uwagę, że odnosi się do akcji misyjnej wśród społeczności skupionej przede wszystkim w głównych ośrodkach i ich przyległościach stosunkowo wówczas jeszcze niewielkiej monarchii Mieszka. Znajdowanie się w jej ramach ludności nieochrzczonej - fakt ten z pewnością nie był obcy Thietmarowi - nie zmieniało tego werdyktu o konwersji ludu, czego zapewne nie należy wyjaśniać bynajmniej samym tylko kronikarskim wyolbrzymianiem sukcesu misyjnego.

Ważniejszy wydaje się w tym wypadku, użyty jako argument na zasadzie analogii, sposób postrzegania przez kronikarza społecznego kręgu cesarstwa, w którym żył, jako zbiorowości chrześcijańskiej. W jego ramach znajdowały się nie tylko obszary wciąż słabo schrystianizowane na poziomie lokalnym, ludności poszczególnych osad, ale też całych zbiorowości plemiennych na północnym Połabiu, gdzie być może w ogóle nie doszło nawet do konwersji przedstawicieli elit. Niemniej kronikarz nie zawahał się w tym wypadku orzec, iż ludy te - począwszy do wielkiego powstania 983 r. - powróciły do pogaństwa już po etapie wcześniejszego przyjęcia chrześcijaństwa (mowa tu o „suscepta christianitate”). Zrzucając zaś panowanie cesarstwa, a konkretnie ucisk saskich margrabiów, miały też porzu-

\footnotetext{
${ }^{8}$ Zainspirowały one Czesława Deptułę (Galla Anonima mit genezy Polski. Studium z historiozofii i hermeneutyki symboli dziejopisarstwa średniowiecznego, Lublin 1990) do rozwinięcia idei drugiego początku Polski jako jej chrztu. Przypisanie tej historiozoficznej koncepcji Gallowi budzi jednak wątpliwości, gdyż „oświecenie” Polski trudno wprost uznać za jej nowe stworzenie, szerzej zob. np. S. Rosik, The world of paganism in Gallus' narrative (Reconnaissance), w: Gallus Anonymous and his chronicle in the context of twelfth-century historiography from the perspective of the latest research, red. K. Stopka, Kraków 2010, s. 91-102.
} 
cić służbę Chrystusowi i św. Piotrowi. O ich przynależności do chrześcijaństwa decydowało więc objęcie ich strukturami chrześcijańskiej monarchii i organizacji diecezjalnej ${ }^{9}$.

Polacy (Poleni) ${ }^{10}$ wraz ze stojącym na ich czele władcą stanowią zatem w przedstawieniu Thietmara jeden chrześcijański organizm polityczny, którego władza obejmuje obszary zamieszkiwane przez ludność słabiej schrystianizowaną bądź - w zakresie jednostkowych nawróceń - wcale. Przekonuje o tym choćby wzmianka o działalności biskupa Soli Kołobrzeskiej, Reinberna, który jako sufragan metropolii gnieźnieńskiej od roku 1000 unicestwiał idolatrię w nadbałtyckiej strefie panowania Bolesława Chrobrego. Kronikarski ogląd ma charakter zewnętrzny, ale oddaje punkt widzenia podzielany przynajmniej przez elitę wczesnopiastowskiej monarchii, partycypującą w obiegu politycznym i kulturalnym zogniskowanym wokół cesarstwa.

Przytoczony passus Thietmara dowodzi zatem, iż na początku XI stulecia już funkcjonowało w tym kręgu wyobrażenie zbiorowe "ludu” Polaków jako wspólnoty rządzonej przez ród Mieszka i już trwale chrześcijańskiej. Pomimo kryzysu władzy w Polsce lat trzydziestych XI w. nie zostało ono zatarte, stając się miarą tożsamości społeczeństwa przywróconej przez Kazimierza Odnowiciela monarchii, w ramach której kontynuowana była chrystianizacja kraju i ludności. Związanie narodzin tej chrześcijańskiej wspólnoty Polaków z chrztem Mieszka I stało się trwałym elementem polskiej tradycji historycznej, a petryfikujące znaczenie w tym zakresie miał już mitologizujący to wydarzenie, m.in. z udziałem legendy o cudownym przejrzeniu niewidomego w dzieciństwie Mieszka, przekaz Galla Anonima.

Powyższe refleksje pozwalają pokusić się o wysunięcie sumarycznych i ogólniejszych wniosków w zakresie kryteriów, jakimi kierowano się w przeszłości, by uznać dane społeczeństwo za chrześcijańskie:

Przedstawienie przez Thietmara Polaków jako zbiorowości chrześcijańskiej łączy się przede wszystkim z aktem chrztu ich władcy i przekonaniem o chrzcie reszty jego poddanych uznanych za jeden lud. Podkreślenie ciężkiej pracy z nimi dokonanej przez biskupa Jordana sugeruje, iż

${ }^{9}$ Thietmar, III, 17; zob. S. Rosik, Interpretacja chrześcijańska religii pogańskich Słowian $w$ świetle kronik niemieckich XI-XII wieku (Thietmar, Adam z Bremy, Helmold), Wrocław 2000, s. 85-96, 168-171.

${ }^{10}$ Mieszko nazywany jest przez Thietmara „dux Poleniorum”, co w polskim przekładzie oddano mianem księcia Polan (por. Thietmar, IV, 55, s. 219). Jednakże, nie wnikając tu w problem istnienia plemienia Polan, warto zwrócić uwagę, iż Thietmar odnosi nazwę Poleni (np. VI, 55 - tu zresztą w tłumaczeniu są już „Polacy”, s. 392) już do postplemiennej rzeczywistości, więc bardziej adekwatne wydaje się używanie dla tego etnonimu przekładu „Polacy”. 
z działalnością chrzcielną łączyło się nauczanie. Jednakże głębokiego przyswojenia prawd wiary i zasad etycznych chrystianizmu nie należy w tym wypadku zakładać, biorąc pod uwagę choćby wzmiankę kronikarza o trudnościach władcy m.in. w egzekwowaniu postów jeszcze za czasów Bolesława Chrobrego ${ }^{11}$. Kluczowe znaczenie ma więc w tym wypadku akt chrztu, który w perspektywie teologicznej wyznacza moment wejścia w łączność z Chrystusem.

Sama wzmianka o obecności biskupa już u progu działalności misyjnej w kraju wskazuje, iż pojawienie się organizacji diecezjalnej stanowi istotny element ważący na uznaniu danej społeczności za chrześcijańską. W sytuacji objęcia ramami diecezji także zbiorowości nieschrystianizowanych, również je uznaje się za włączone do kręgu christianitas. Przesądzają o tym stanie rzeczy racje teologiczne, w myśl których całe ludy włączane są do wspólnoty z Chrystusem na zasadzie objęcia ich ramami instytucji Kościoła pozostającego w łączności z chrześcijańską monarchiąa ${ }^{12}$.

W tym kontekście chrystianizacja przedstawia się jako uformowanie się ludu chrześcijańskiego skupionego wokół monarchii i rozszerzanie się władzy tego organizmu na kolejne społeczności, już uznawane za przynależące do christianitas, a de facto stanowiące dopiero potencjalny obiekt zabiegów misyjnych - likwidacji kultu pogańskiego (idolatrii) i doprowadzania do praktykowania nowej religii. $\mathrm{W}$ tym ujęciu chrystianizacja w pierwszej kolejności rysuje się jako włączanie jednostek i całych ludów do wspólnoty christianitas, a likwidacja pogaństwa to środek do tego celu, w wymiarze ponadindywidualnym nieraz odwlekany w czasie.

Zatem paradygmat traktujący chrystianizację na zasadzie paralelnej likwidacji pogaństwa i zaprowadzania chrześcijaństwa ${ }^{13}$, a w konsekwencji nasuwający pytanie, jak daleko postąpić ma konwersja indywidualna i związana z nią zmiana obyczajów, by uznać społeczeństwo skupione w ramach danej państwowości za chrześcijańskie, nie przystaje do kryteriów zastosowanych w tej mierze przez Thietmara. Zasadniczym mechanizmem chrystianizacji w świetle jego przekazu wydaje się bowiem nawiązywanie więzi ze wspólnotą chrześcijańską skupioną

${ }^{11}$ Thietmar, VIII, 2.

${ }^{12}$ Szerzej w tej sprawie zob. H.-D. Kahl, Die ersten Jahrhunderte des missionsgeschichtlichen Mittelalters. Bausteine für eine Phänomenologie bis ca. 1050, w: Kirchengeschichte als Missionsgeschichte, t. 2: Die Kirchen des früheren Mittelalters, cz. 1, red. K. Schäferdiek, München 1978, s. 11-76, szczególnie s. 73-75; a także np. B. Wavra, Salzburg und Hamburg. Erzbistumsgründung und Missionspolitik in karolingischer Zeit, Berlin 1991, s. 15, 28-31; zob. też wyżej, przyp. 11.

${ }^{13}$ Tak np. W. Dziewulski, Postępy chrystianizacji i proces likwidacji pogaństwa $w$ Polsce wczesnofeudalnej, Wrocław 1964. 
wokół monarchii i organizacji diecezjalnej tak na poziomie indywidualnym (przez chrzest), jak i zbiorowym.

Postęp chrystianizacji wyznacza więc rozszerzanie tak uformowanej wspólnoty ochrzczonych i rozciąganie jej dominacji względem sąsiadów, stanowiących potencjalną przestrzeń ewangelizacji. W tej perspektywie chrystianizacja przedstawia się jako pierwiastek więziotwórczy w ramach społeczeństwa podległego monarchii, aczkolwiek zwłaszcza na początkowym jej etapie okazywała się też elementem potęgującym opór przeciw utrwalaniu władzy Piastów, czego dowodzi antykościelny aspekt rewolty społecznej w Polsce lat trzydziestych XI w.

Przekaz Thietmara wyraża pogląd z zewnątrz, uwarunkowany jego Sitz-im-Leben, jednakże przypuszczać należy, że kategorie, którymi się posłużył, nie były obce elicie polskiej monarchii na początku XI w., zwłaszcza w tak zasadniczym wymiarze jak samoidentyfikacja z chrystianizmem. Chrześcijańska tożsamość stała się więc już w tym czasie elementem tak postrzegania Polaków z zewnątrz, jak też samoświadomości ich elity. Przekonanie, iż chrześcijańską tożsamość zyskał ów lud już w czasach Mieszka I, jako fakt społeczno-kulturowy stało się dziedzictwem kolejnych pokoleń wciąż chrystianizowanego społeczeństwa piastowskiego.

Mityzacja zaś tego zbiorowego wyobrażenia o przełomowej religijnej transformacji zredukowała jej źródło do chrztu Mieszka, natomiast sama przemiana po Gallowym „oświeceniu” Polski przybrała formę nośnej do dziś metafory jej chrztu. Zdążyła zawędrować na karty naukowych, powstałych w XX stuleciu ${ }^{14}$, opracowań historycznych na temat Polski średniowiecznej wciąż w związku z konwersją założyciela dynastii Piastów. Obecnie coraz bardziej upowszechniony model procesualnej, długofalowej interpretacji „chrztu” Polski osłabia znaczenie symbolicznego roku 966 w charakterystyce chrystianizacji jej społeczeństwa, ale bynajmniej nie oznacza rezygnacji z samej metafory antropomorfizującej obraz przemian religijnych tradycyjnie $\mathrm{z}$ tą datą wiązanych.

To jej procesualne zastosowanie w nauce zderza się jednak $\mathrm{z}$ samą wymową metafory chrztu, którego symbolika i teologia zakłada całkowitą anihilację „starego stworzenia” i zastąpienie go „nowym”. Tymczasem proces całkowitej likwidacji pogaństwa, jego reliktów czy nowych postaci, jako pierwiastka przeciwstawiającego się chrystianizacji w społeczeństwie polskim, nigdy przecież nie nastąpił. Dlatego warto wskazać alternatywę dla tego sposobu stawiania pytania o moment, w którym

${ }^{14}$ R. Grodecki, Dzieje Polski do r. 1194, w: R. Grodecki, S. Zachorowski, J. Dąbrowski, Dzieje Polski średniowiecznej, t. 1: Do roku 1333, oprac. J. Wyrozumski, Kraków 1995, s. 68 n. 
społeczeństwo staje się chrześcijańskie. Wskazuje ją namysł nad przytoczoną u progu tych rozważań wiadomością Thietmara, który uświadamia, że zaistnienie poglądu o chrześcijańskim obliczu społeczeństwa jest elementem procesu historycznego, manifestującym się przede wszystkim w ewoluującym, złożonym fenomenie zbiorowej tożsamości, nieraz reprezentowanej jedynie przez elity społeczeństwa bądź nawet tylko nadawanej pewnym grupom z zewnątrz. 